\title{
High-porosity channels for melt migration in the mantle: Top is the dunite and bottom is the harzburgite and lherzolite
}

\author{
Yan Liang, ${ }^{1}$ Alan Schiemenz, ${ }^{1,2}$ Marc A. Hesse, ${ }^{1,3}$ E. Marc Parmentier, ${ }^{1}$ and Jan S. Hesthaven ${ }^{2}$ \\ Received 1 June 2010; revised 1 July 2010; accepted 7 July 2010; published 13 August 2010.
}

[1] High-porosity dunite channels are important pathways for melt migration in the mantle. To better understand the first order characteristics of the high-porosity melt channel and its associated peridotite lithologies in an upwelling mantle, we conducted high-resolution numerical simulations of reactive dissolution in a deformable porous medium. Results from this study show that high-porosity dunite channels are transient and shallow parts of pathways for melt migration in the mantle. The lower parts of a high-porosity channel are harzburgite and lherzolite. The size and dimension of dunite channels depend on the amplitude of lateral porosity variations at the base of the melting column, whereas the depth of dunite channel initiation depends on the melt flux entering the channel from below. Compaction and interaction between compaction and dissolution play a central role in distributing melt in the dunite channel. A wide orthopyroxene-free dunite channel may contain two or more high-porosity melt channels. A primary highporosity melt channel developed in the deep mantle may excite secondary melt channels in the shallow part of the melting column. The spatial relations among the high-porosity melt channel and its associated lithologies documented in this study may shed new light on a number of field, petrological, and geochemical observations related to melt migration in the mantle. Citation: Liang, Y., A. Schiemenz, M. A. Hesse, E. M. Parmentier, and J. S. Hesthaven (2010), High-porosity channels for melt migration in the mantle: Top is the dunite and bottom is the harzburgite and lherzolite, Geophys. Res. Lett., 37, L15306, doi:10.1029/2010GL044162.

\section{Introduction}

[2] Orthopyroxene-free dunite dikes, veins, or irregularly shaped bodies have been frequently observed in mantle sections of ophiolites where mantle rocks are exposed on the surface. These dunite bodies make up 5-15\% of the mantle in Oman ophiolite and their sizes range from tens of millimeters to 200 meters in width and tens of meters to at least $10 \mathrm{~km}$ in length [e.g., Boudier and Nicolas, 1985; Nicolas, 1989; Kelemen et al., 1997]. Several lines of evidence suggest that orthopyroxene-free dunites represent remnants of high-porosity melt channels through which basaltic magmas generated in the deep mantle were extracted to

\footnotetext{
${ }^{1}$ Department of Geological Sciences, Brown University, Providence, Rhode Island, USA.

${ }^{2}$ Division of Applied Mathematics, Brown University, Providence, Rhode Island, USA.

${ }^{3}$ Now at Department of Geological Sciences, University of Texas at Austin, Austin, Texas, USA.
}

Copyright 2010 by the American Geophysical Union. 0094-8276/10/2010GL044162 the surface [e.g., Kelemen et al., 1997, and references therein]. The formation of dunite channels involves dissolution of pyroxene and precipitation of olivine when olivinenormative basalts percolate through a partially molten mantle [e.g., Quick, 1981a; Daines and Kohlstedt, 1994; Aharonov et al., 1995; Kelemen et al., 1995a, 1995b; Asimow and Stolper, 1999; Spiegelman et al., 2001; Morgan and Liang, 2003, 2005]. It has been suggested that an interconnected coalescing network of high-porosity orthopyroxene-free dunite channels allow basaltic melts to efficiently segregate from their source region while preserving their geochemical signatures developed at depth [e.g., Kelemen et al., 1997, 2000; Braun and Kelemen, 2002]. However, the depth of dunite channel initiation in an upwelling mantle remains uncertain. It is not known if the relatively shallow occurrence of dunite bodies in the mantle section of ophiolites is due to limited field exposure or processes related to dunite channel formation in the mantle. It is also not known if high-porosity harzburgite channels or orthopyroxene-bearing dunite channels exist in the mantle. Is the porosity of a dunite channel always higher than that in the surrounding harzburgite matrix? How is melt distributed within a dunite or harzburgite channel? Is dunite channel synonymous with high-porosity melt channel? To address at least part of these first order questions, we conducted twodimensional (2-D) high-order accurate numerical simulations of reactive porous flow in an upwelling deformable mantle column. Results from our numerical simulations show that dunite channels are the shallow part of highporosity melt channels that extend significantly deeper into the upwelling mantle. Deep harzburgite and lherzolite channels overlain by shallow dunite channels are the natural consequence of partial melting and melt-rock reaction during melt migration in the mantle.

\section{Model Setup}

[3] We consider reactive dissolution in a 2-D upwelling column that consists of a soluble mineral, an insoluble mineral, and an interconnected melt network in a vertical gravitational field in which solubility of the soluble mineral increases upward along the vertical direction. This setup is directly relevant to melt migration in the mantle, as melt generated in the deeper part of the melting column is not in chemical equilibrium with the overlying mantle and has a strong tendency to dissolve pyroxenes at shallow depth [e.g., O'Hara, 1965; Stolper, 1980; Elthon and Scarfe, 1984; Kelemen, 1990; Asimow and Stolper, 1999]. Hence the soluble mineral may be identified as orthopyroxene (opx for short, and possibly clinopyroxene), and the insoluble mineral may be taken as olivine. For simplicity, we treat olivine + opx + melt as an effective binary system in which 


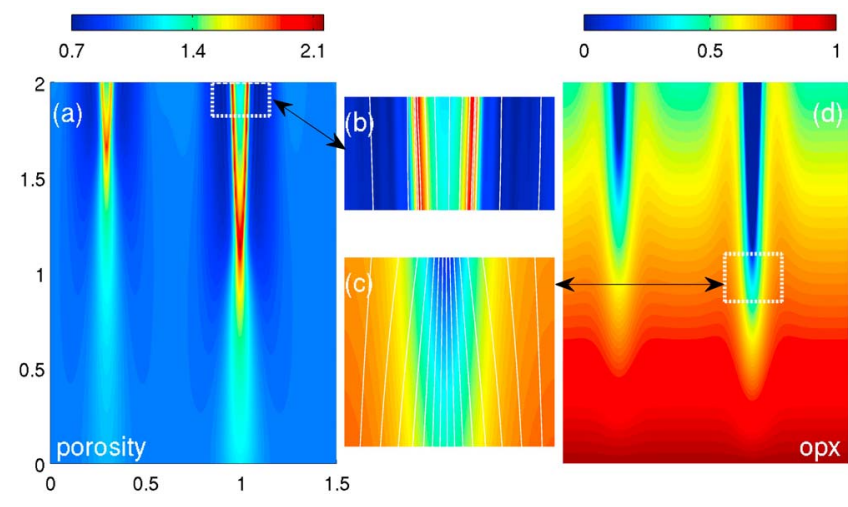

Figure 1. Steady-state distributions of (a) porosity and (d) the soluble mineral opx in a short upwelling column. (b) Close-up view of the porosity field in the highlighted area near the top of the wider channel. (c) Close-up view of the opx field in the highlighted region near the bottom of the wider dunite channel. Dark blue regions in Figure 1d mark the opx-free dunite channels. White curves in Figures $1 \mathrm{~b}$ and $1 \mathrm{c}$ are streamlines of the melt. The two dunite channels were initiated by two small but sustained Gaussian perturbations in porosity at the bottom of the upwelling column. Steady state is established after one solid overturn $(t \geq 2)$. Porosity and opx modal abundance are normalized to their respective background values ( $2 \%$ and $15 \%$, respectively) at the bottom of the upwelling column.

the interstitial melt and minerals are in local chemical equilibrium. To maintain local chemical equilibrium in the upwelling column, a melt percolating upward, therefore, must dissolve opx. To map out the spatial distribution of opx-free dunite in the upwelling column, we explicitly track the modal abundance of opx in the simulation domain by solving a mass conservation equation for opx. Early studies of reactive dissolution in a porous medium [e.g., Ortoleva et al., 1987; Steefel and Lasaga, 1990; Aharonov et al., 1995; Spiegelman et al., 2001; Spiegelman and Kelemen, 2003] have shown that a positive feedback between dissolution and melt flow results in the formation of high-porosity melt channels along the melt flow direction. With increasing rate of solid upwelling, the rate of high-porosity channel formation decreases because effective dissolution time is decreased. To facilitate melt channel formation in an upwelling column, we introduce small but sustained Gaussian perturbations in melt fraction at the base of the simulation domain. Small perturbations in melt fraction may be realized by the presence of chemically and/or lithologically heterogeneous materials that start to melt at a greater depth than the background mantle. With sustained perturbation it is possible to obtain quasi steady-state solutions that allow us to examine the first order characteristics of the melt channel in an upwelling column. A brief summary of the governing equations, initial and boundary conditions, and numerical methods is given in the auxiliary material. ${ }^{1}$

\section{Numerical Results}

[4] Figures 1 and 2 show two examples of the calculated porosity and opx abundance in the computational domain

${ }^{1}$ Auxiliary materials are available in the HTML. doi:10.1029/ 2010GL044162. after each system has approached quasi steady-state. Figure 1 is a case of a short column fed by two sustained perturbations of different amplitudes. Figure 2 is a case of a long column fed by one sustained perturbation. Four melt channels and two dunite channels are observed in Figure 1, whereas six melt channels and three dunite channels are observed in Figure 2. Key observations and conclusions from our numerical simulations are summarized below.

[5] First of all, dunite bodies are not synonymous with high-porosity melt channels, although there is a strong correlation between them (cf. Figures 1a and 1d, Figures 2a and $2 b$, Figures $3 a-3 c$ and $3 d-3 f$ ). The melt channels extend all the way to the bottom of the computational domain (Figures 1a and 1b), whereas opx-free dunites (the dark blue region in Figures 1d and $2 \mathrm{~b}$ ) emerge at the middle to upper part of the simulation domain. Depending on the clinopyroxene abundance in the mantle, the lower part of the highporosity melt channel is opx-bearing dunite, harzburgite, and possibly lherzolite. This is consistent with the onedimensional steady-state model of Asimow and Stolper [1999] in which they showed the depth of pyroxene exhaustion in an upwelling melting column is positively correlated with the strength of melt focusing. Formation of harzburgite from lherzolite by pervasive melt-rock reaction in the upper mantle is also supported by the presence of dunite-harzburgite-lherzolite sequence in lherzolite subtype ophiolites such as Trinity and Lanzo as well as laboratory dissolution study [e.g., Boudier and Nicolas, 1985; Nicolas, 1989; Kelemen et al., 1992; Morgan and Liang, 2005] and is likely to play an important role in the formation of highporosity melt channels in the lower part of an upwelling melting column.

[6] Secondly, porosities of the opx-bearing dunite and harzburgite/lherzolite channels are higher than their surrounding matrices, whereas the porosity of the opx-free dunite channel is highly variable. A melt channel in the lower part of the domain bifurcates into two high-porosity branches within the wider dunite channel (Figures 1 and 2). In the absence of opx dissolution (hence porosity generation), compaction in the central part of the larger dunite forces melt to localize along the boundaries of the dunite channel. In fact, porosity of the upper central part of the wider dunite in Figure 2 is lower than that of the far-field harzburgite matrix. High-porosity opx-free dunite channels are therefore transient and shallow parts of pathways for melt migration in the mantle.

[7] Thirdly, low-porosity compacting boundary layers form around high-porosity melt channels (deep blue regions in Figures 1a and 2a). The abundance of opx in the compacting boundary layer is higher than that in the surrounding matrix (Figures 1d and 3), as a result of reduction in the local melt flux. The presence of a low-porosity compacting boundary layer hinders lateral melt transport between the channel and the far-field matrix, reducing melt flow into the high-porosity channel in the upper part of the melting column. Melt in the dunite channel is drawn mostly from a broader region below the dunite that has a width comparable to the distance between the ends of the two compacting boundary layers on either side of the dunite channel (Figures 1a and 1d). In terms of melt extraction, a dunite channel may be analogous to a leaky straw with melt drawn mostly at its tip or orifice. Individual melt channels, therefore, may be fed by geochemically distinct reservoirs, so 

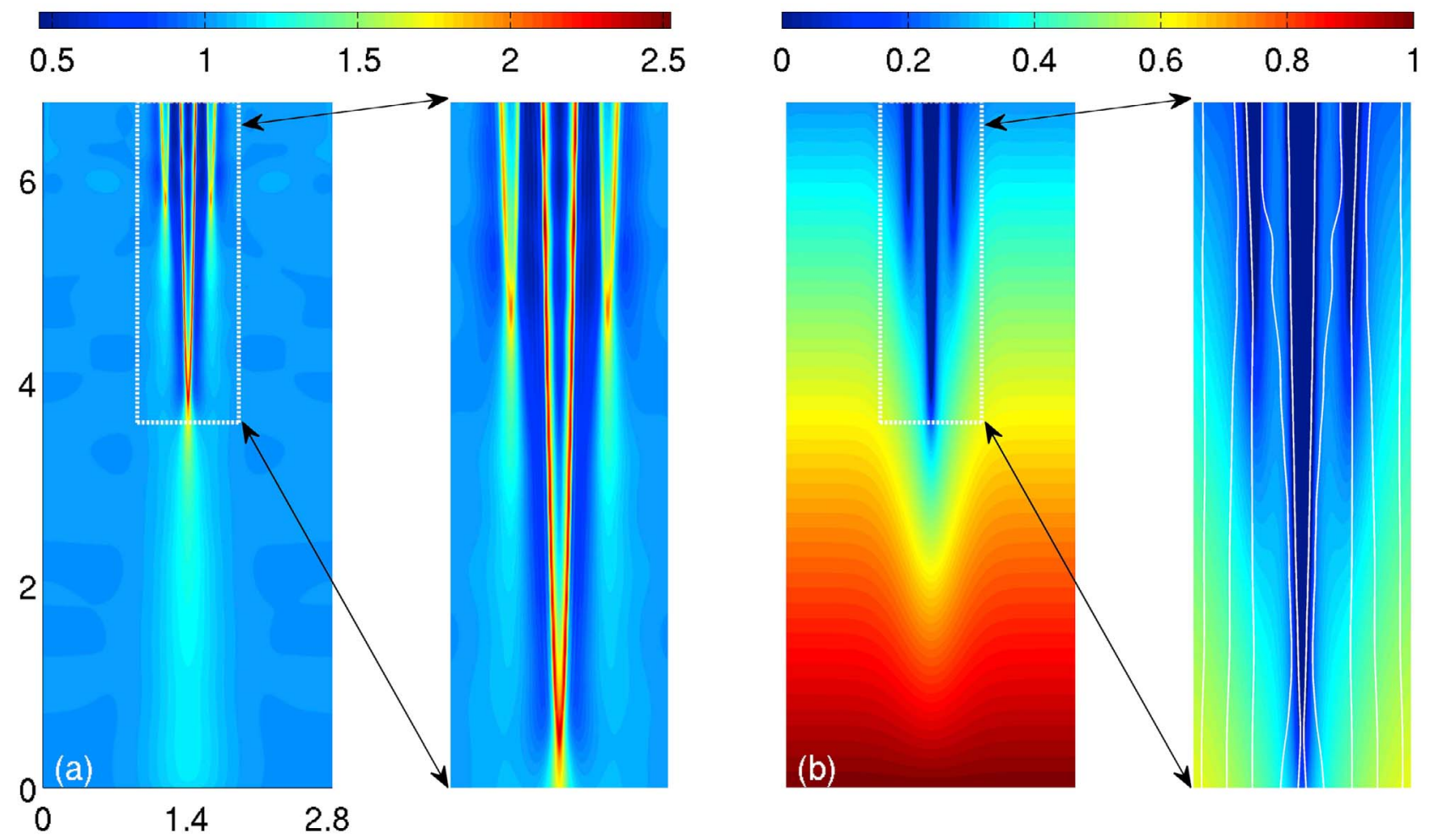

Figure 2. Distributions of (a) porosity and (b) opx in a long upwelling column at time $t=7$. Dark blue regions in Figure $2 \mathrm{~b}$ mark the opx-free dunite channels. Close-up views of the porosity and opx fields in the highlighted region are also shown. The white lines in Figure 2b are melt streamlines. The deeper melt and dunite channels along the center plane were initiated by one small but sustained Gaussian perturbation in porosity at the bottom and are referred as primary channel in the text. The two smaller dunite channels are referred as secondary channels. Porosity and opx modal abundance are normalized to their respective background values ( $2 \%$ and $40 \%$, respectively) at the bottom of the upwelling column.

long as their spatial separation is greater than the width of the compacting boundary layer.

[8] The differences in the size and dimension of the two dunite channels in Figure 1d are due to a difference in the amplitude of the boundary perturbation in porosity. The boundary perturbation is also responsible for the formation of the wider and deeper primary dunite channel in Figure $2 b$. However, the two smaller secondary dunite channels in Figure $2 \mathrm{~b}$ emerge only after the formation of the primary channel. Figures 3a-3f display the porosity and opx abundance in the highlighted region in Figure 2 at early times $(t=2,3,4)$ when the system has not reached a quasi-steady state (Figure 2 at $t=7$ ). The two secondary channels were excited by melt reorganization in and around the compacting boundary layer surrounding the primary channel. The melt has a significant horizontal flow component in the lower part of the inter-channel region (Figure 2b), permitting at least partial communication between the primary and secondary channels.

[9] Finally, the depth of dunite channel initiation depends strongly on the total melt flux entering the channel from below, as noted by Asimow and Stolper [1999]. The total melt flux at the bottom of the dunite channel depends on the total incoming melt flux across the perturbed region feeding into the overlying high-porosity channels in the dunite, the solubility gradient of opx, and to a lesser degree, the mass flux of opx entering the domain. Numerical simulations using several choices of opx solubility and upwelling rate show that the total melt flux coming out of the dunite channel at the top of the domain is inversely proportional to the solubility of opx at the bottom of the dunite channel. Hence, given the functional form of opx solubility, it may be possible to constrain the depth of dunite channel initiation in the mantle in the future.

\section{Geological Applications}

[10] Although simplified in the model setup, the spatial relations among the high-porosity melt channel, dunite channel, harzburgite and possibly lherzolite channels documented in our numerical simulations may shed new light on a number of field, petrological, and geochemical observations related to melt migration in the mantle. The close proximity among dunite bodies of different width in the mantle sections of ophiolites and peridotite massifs [e.g., Kelemen et al., 2000; Braun and Kelemen, 2002; Suhr et al., 2003; Savelieva et al., 2008] may be in part due to differences in their depth of initiation and the presence of secondary channels. Compaction in and around a dunite channel and interaction between compaction and dissolution play a central role in distributing melt in the dunite channel. A wide opx-free dunite channel may contain two or more high-porosity melt channels. Flow rate in the narrower melt channel is higher than that in a wider channel, expediting the delivery of short-lived isotopes to the surface. In situ crys- 

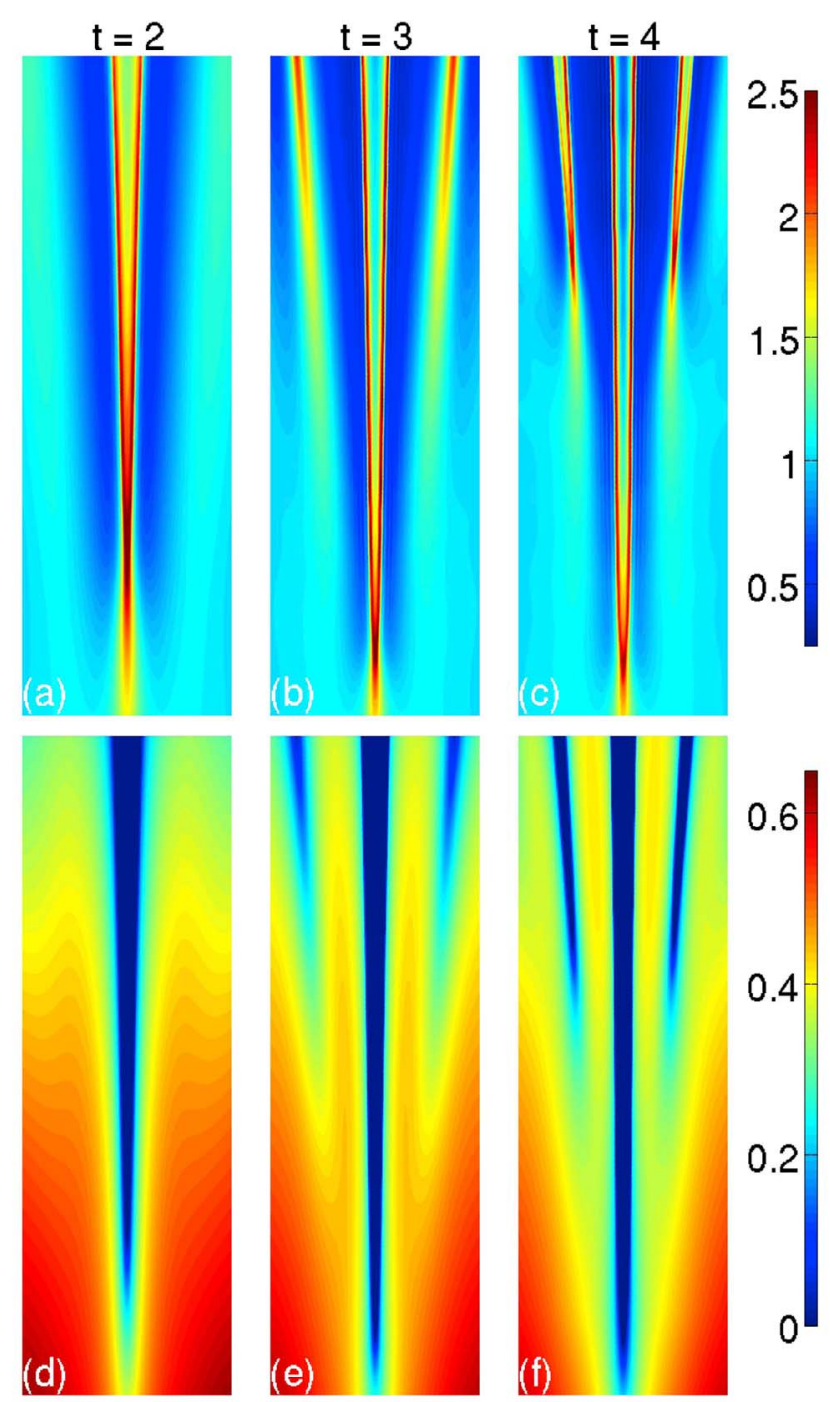

Figure 3. Distributions of $(\mathrm{a}-\mathrm{c})$ porosity and $(\mathrm{d}-\mathrm{f})$ opx in the highlighted region in the long upwelling column shown in Figures $2 \mathrm{a}$ and $2 \mathrm{~b}$ at three selected times. Note the two secondary melt channels near the top of the upwelling column are opx-bearing dunite in Figure $3 b$, but opx-free dunite in Figure 3c. Also note the rotation of the secondary melt and dunite channels at $t=3,4$ and 7 (Figure 2). Although the porosity and melt flow fields are still timedependent, the geometry of the melt channels and dunite channels are practically independent of time after one solid overturn $(t \geq 6.75)$.

tallization in and focusing of melt from the high-porosity region near a thermal boundary layer may provide a possible explanation for the occurrence of clinopyroxene megacrystal trails and at least some clinopyroxenite, websterite, and orthopyroxenite veins or dikes within the opx-free dunite in the mantle sections of ophiolites [e.g., Quick, 1981b; Kelemen et al., 1995a; Maaløe, 2005; Morgan et al., 2008; Savelieva et al., 2008]. These pyroxene crystals or pyroxenite veins have often been observed near the boundaries of dunite dikes or bodies. Localization of melt along the boundaries of or within opx-free dunite channel reduces local viscosity and may promote deformation, melt relocalization, and possibly fracture formation in the shallow mantle [e.g., Holtzman et al., 2003]. Spatial variations in opx abundances around a dunite channel may be used to deduce the width of the compacting boundary layer, which in turn may be used to constrain the rheology of the upwelling mantle. Lateral variations in porosity and pyroxene abundance across a high-porosity melt channel system and their close association with boundary perturbation (i.e., mantle heterogeneity) observed in our numerical study may provide a framework for understanding chemical variations across dunite-harzburgite and dunite-harzburgitelherzolite sequences in ophiolites and peridotite massifs [e.g., Quick, 1981a; Kelemen et al., 1995a; Takahashi, 1992; Kubo, 2002; Suhr et al., 2003; Braun, 2004; Morgan et al., 2008]. Fossilized dunite channels have only been observed in the top $10-20 \mathrm{~km}$ of the mantle section of ophiolites, yet melting initiates at greater depth beneath the mid-ocean ridges. If high-porosity harzburgite and lherzolite channels are present in the lower part of an upwelling mantle column, one must reassess the geochemical consequences of channelized melt flow under such a setting [e.g., Lundstrom, 2000; Jull et al., 2002; Spiegelman and Kelemen, 2003; Liang, 2008].

[11] Acknowledgments. We wish to thank Peter Kelemen, Greg Hirth, and Yinhua Xia for helpful discussions, Peter Kelemen for his comments and suggestions to an earlier version of the manuscript. Constructive reviews by David Kohlstedt and an anonymous reviewer helped to clarify this manuscript and are greatly appreciated. This work was supported by a CMG grant from the US National Science Foundation (DMS-0530862).

\section{References}

Aharonov, E., J. A. Whitehead, P. B. Kelemen, and M. Spiegelman (1995), Channeling instability of upwelling melt in the mantle, J. Geophys. Res., 100, 20,433-20,450, doi:10.1029/95JB01307.

Asimow, P. D., and E. M. Stolper (1999), Steady-steady mantle-melt interactions in one dimension: I. Equilibrium transport and melt focusing, J. Petrol., 40, 475-494, doi:10.1093/petrology/40.3.475.

Boudier, F., and A. Nicolas (1985), Harzburgite and lherzolite subtypes in ophiolitic and oceanic environments, Earth Planet. Sci. Lett., 76, 84-92, doi:10.1016/0012-821X(85)90150-5.

Braun, M. G. (2004), Petrologic and microstructural constraints on focused melt transport in dunites and the rheology of the shallow mantle, Ph.D. thesis, Mass. Inst. of Technol., Cambridge.

Braun, M. G., and P. B. Kelemen (2002), Dunite distribution in the Oman Ophiolite: Implications for melt flux through porous dunite conduits, Geochem. Geophys. Geosyst., 3(11), 8603, doi:10.1029/2001GC000289.

Daines, M. J., and D. L. Kohlstedt (1994), The transition from porous to channelized flow due to melt/rock reaction during melt migration, Geophys. Res. Lett., 21, 145-148, doi:10.1029/93GL03052.

Elthon, D., and C. M. Scarfe (1984), High-pressure phase equilibria of a high-magnesia basalt and the genesis of primary oceanic basalts, Am. Mineral., 69, 1-15.

Holtzman, B. K., N. J. Groebner, M. E. Zimmerman, S. B. Ginsberg, and D. L. Kohlstedt (2003), Stress-driven melt segregation in partially molten rocks, Geochem. Geophys. Geosyst., 4(5), 8607, doi:10.1029/ $2001 \mathrm{GC} 000258$.

Jull, M., P. B. Kelemen, and K. Sims (2002), Consequences of diffuse and channeled porous melt migration on uranium series disequilibra, Geochim. Cosmochim. Acta, 66, 4133-4148, doi:10.1016/S0016-7037(02) 00984-5.

Kelemen, P. B. (1990), Reaction between ultramafic rock and fractionating basaltic magma I. Phase relations, the origin of calc-alkaline magma series, and the formation of discordant dunite, J. Petrol., 31, 51-98.

Kelemen, P. B., H. J. B. Dick, and J. F. Quick (1992), Formation of harzburgite by pervasive melt/rock reaction in the upper mantle, Nature, 358, 635-641, doi:10.1038/358635a0.

Kelemen, P. B., N. Shimizu, and V. J. M. Salters (1995a), Extraction of mid-ocean-ridge basalt from the upwelling mantle by focused flow of melt in dunite channels, Nature, 375, 747-753, doi:10.1038/375747a0.

Kelemen, P. B., J. A. Whitehead, E. Aharonov, and K. A. Jordahl (1995b), Experiments on flow focusing in soluble porous media, with application 
to melt extraction from the mantle, J. Geophys. Res., 100, 475-496, doi:10.1029/94JB02544.

Kelemen, P. B., G. Hirth, N. Shimizu, M. Spiegelman, and H. J. B. Dick (1997), A review of melt migration processes in the adiabatically upwelling mantle beneath oceanic spreading ridges, Philos. Trans. R. Soc. A, 355, 282-318.

Kelemen, P. B., M. Braun, and G. Hirth (2000), Spatial distribution of melt conduits in the mantle beneath oceanic spreading ridges: Observations from the Ingalls and Oman ophiolites, Geochem. Geophys. Geosyst., 1(7), 1005, doi:10.1029/1999GC000012.

Kubo, K. (2002), Dunite formation processes in highly depleted peridotite: Case study of the Iwanaidake peridotite, Hokkaido, Japan, J. Petrol., 43, 423-448, doi:10.1093/petrology/43.3.423.

Liang, Y. (2008), Simple models for concurrent melting and melt migration in an upwelling heterogeneous mantle column: Analytical solutions, Geochim. Cosmochim. Acta, 72, 3804-3821, doi:10.1016/j.gca.2008. 05.050 .

Lundstrom, C. C. (2000), Models of U-series disequilibria generation in MORB: The effect of two scales of melt porosity, Phys. Earth Planet. Inter., 121, 189-204, doi:10.1016/S0031-9201(00)00168-0.

Maaløe, S. (2005), The dunite bodies, websterite and orthopyroxenite dikes of the Leka ophiolite complex, Norway, Mineral. Petrol., 85, 163-204, doi:10.1007/s00710-005-0085-5.

Morgan, Z. T., and Y. Liang (2003), An experimental and numerical study of the kinetics of harzburgite reactive dissolution with applications to dunite dike formation, Earth Planet. Sci. Lett., 214, 59-74, doi:10.1016/S0012-821X(03)00375-3.

Morgan, Z. T., and Y. Liang (2005), An experimental study of the kinetics of lherzolite reactive dissolution with applications to melt channel formation, Contrib. Mineral. Petrol., 150, 369-385, doi:10.1007/s00410-0050033-8.

Morgan, Z. T., Y. Liang, and P. B. Kelemen (2008), Significance of the composition profiles associated with dunite bodies in the Josephine and Trinity ophiolites, Geochem. Geophys. Geosyst., 9, Q07025, doi:10.1029/2008GC001954.

Nicolas, A. (1989), Structures of Ophiolites and Dynamics of Oceanic Lithosphere, Kluwer Acad., Dordrecht, Netherlands.

O'Hara, M. J. (1965), Primary magmas and the origin of basalts, Scott. J. Geol., 1, 19-40, doi:10.1144/sjg01010019.

Ortoleva, P., J. Chadam, E. Merino, and A. Sen (1987), Geochemical selforganization. I. Reactive-transport feedbacks and modeling approach, Am. J. Sci., 287, 979-1007.
Quick, J. E. (1981a), The origin and significance of large, tabular dunite bodies in the Trinity peridotite, northern California, Contrib. Mineral. Petrol., 78, 413-422, doi:10.1007/BF00375203.

Quick, J. E. (1981b), Petrology and petrogenesis of the Trinity peridotite, an upper mantle diapir in the eastern Klamath Mountains, northern California, J. Geophys. Res., 86, 11,837-11,863, doi:10.1029/ JB086iB12p11837.

Savelieva, G. N., A. V. Sobolev, V. G. Batanova, P. V. Suslov, and G. Brügmann (2008), Structure of melt flow channels in the mantle, Geotectonics, Engl. Transl., 42, 430-447, doi:10.1134/S0016852108060022.

Spiegelman, M., and P. B. Kelemen (2003), Extreme chemical variability as a consequence of channelized melt transport, Geochem. Geophys. Geosyst., 4(7), 1055, doi:10.1029/2002GC000336.

Spiegelman, M., P. B. Kelemen, and E. Aharonov (2001), Causes and consequences of flow organization during melt transport: The reaction infiltration instability in compactable media, J. Geophys. Res., 106, 2061-2077, doi:10.1029/2000JB900240.

Steefel, C. I., and A. C. Lasaga (1990), Evolution of dissolution patterns: Permeability change due to coupled flow and reaction, in Chemical Modeling of Aqueous Systems II, edited by D. C. Melchior and R. L. Bassett, ACS Symp. Ser., 416, 212-225, doi:10.1021/bk-1990-0416. ch016.

Stolper, E. M. (1980), A phase diagram for mid-ocean ridge basalts: Preliminary results and implications for petrogenesis, Contrib. Mineral. Petrol., 74, 13-27, doi:10.1007/BF00375485.

Suhr, G., E. Hellebrand, J. E. Snow, H. A. Seck, and A. W. Hofmann (2003), Significance of large, refractory dunite bodies in the upper mantle of the Bay of Islands ophiolite, Geochem. Geophys. Geosyst., 4(3), 8605, doi:10.1029/2001GC000277.

Takahashi, N. (1992), Evidence for melt segregation towards fractures in the Horoman mantle peridotite complex, Nature, 359, 52-55, doi: $10.1038 / 359052 \mathrm{a} 0$.

M. A. Hesse, Department of Geological Sciences, University of Texas at Austin, Austin, TX 78712, USA.

J. S. Hesthaven, Division of Applied Mathematics, Brown University, Providence, RI 02912, USA.

Y. Liang, E. M. Parmentier, and A. Schiemenz, Department of Geological Sciences, Brown University, Providence, RI 02912, USA. (yan_liang@brown.edu) 